\title{
Implementasi Kebijakan Pengelolaan Parkir Kota Bandung
}

\author{
${ }^{1}$ Asep Hidayat, ${ }^{2}$ Aris Munandar, ${ }^{3}$ Armidiana \\ ${ }^{1}$ Administrasi Publik Fakultas Ilmu Sosial dan Ilmu Politik UIN Sunan Gunung Djati Bandung; \\ dr.asephi62@gmail.com \\ ${ }^{2}$ Institut Agama Islam Sukabumi; risris.munandar89@gmail.com \\ ${ }^{3}$ Administrasi Publik Fakultas Ilmu Sosial dan Ilmu Politik UIN Sunan Gunung Djati Bandung; \\ sitijuliyani1@gmail.com
}

\begin{abstract}
The Parking Tax Revenue, from 2013 to 2016, experienced ups and downs and less significant increase, especially in 2015, it run into a very significant decrease from the target. This study aims to analyze the implementation of parking management policy in buildings and parking lots in Bandung. The Research uses a qualitative approach, with descriptive research type. Data collection techniques used are in-depth interviews and literature study. The determination of informants in this study was carried out using the purposive technique. To analyze the data, this research uses qualitative data analysis, namely by searching and systematically compiling data obtained from interviews, field notes, and other materials. The results of this study indicate that the implementation of Peraturan Wali Kota No. 1005 of 2014 regarding Parking Lease Prices and Technical Guidelines for Parking Management in Buildings and Parking Grounds in Bandung City has not been running optimally, because it has been seen from several factors that influence it.
\end{abstract}

Keywords: Public Policy, Policy Implementation, Parking Management, Bandung City.

\section{Pendahuluan}

Kota Bandung merupakan sebuah kota di Indonesia yang berpenduduk padat dan tercatat sebagai daerah yang penduduknya memiliki sejumlah kendaraan baik roda dua maupun roda empat yang cukup tinggi. Hal tersebut tentu menjadikan alasan bahwa Bandung menjadi salah satu kota dengan destinasi liburan tertinggi di Pulau Jawa. sehingga menyebabkan tingginya intensitas kendaraan keluar masuk di kota Bandung. Melihat potensi tersebut Kota Bandung berpeluang meningkatkan pendapatan asli daerah dari sektor pajak parkir apabila dikelola dengan baik dan benar. Pengelolaan tersebut sebenarnya bisa merujuk pada aturan hukum yang berlaku seperti pada PP Nomor 65 Tahun 2001 tentang Pajak Daerah.

Salah satu proses penting dalam menilai berhasil tidaknya suatu kebijakan publik ialah implementasi kebijakan. Mazmanian dalam (Agustino, 2014) membuat definisi implementasi kebijakan sebagai pelaksanaan keputusan-keputusan dalam suatu kerangka kebijakan, yang diwujudkan dalam bentuk peraturan perundang-undangan, instruksi dan himbauan yang sifatnya imperatif atau keputusan badan peradilan lainnya. Pada dasarnya, keputusan tersebut dimaksudkan untuk menyentuh masalah yang ingin diatasi, menguraikan secara jelas dan lugas sasaran dan tujuan yang hendak dicapai, serta memuat sejumlah usaha untuk mengorganisir dan mengarahkan proses pelaksanaannya. Van Meter dan Van Horn dalam (Agustino, 2014) menguraikan definisi implementasi kebijakan publik sebagai sejumlah tindakan yang dijalankan baik itu secara individu maupun atau kelompok dari unsur pemerintah dan swasta dalam rangka agar tujuan-tujuan yang sebelumnya telah disepakati bersama oleh lembaga dapat tercapai. Sedangkan menurut Rose dalam (Nawawi, 2009), 
implementasi kebijakan publik adalah berbagai macam kegiatan yang akan selalu berkaitan dengan segala konsekuensi-konsekuensinya yang dilakukan oleh sejumlah aktor yang berkepentingan sebagai suatu keputusan bersama. Implementasi kebijakan juga sering dianggap sebagai bentuk pengoprasionalisasian aktivitas yang telah diatur dan digariskan menurut peraturan hukum sehingga menjadi suatu konsensus bersama diantara para pemangku kepentingan baik secara individu aktor maupun organiasi publik atau privat. (Wahab, 2012).

Menurut Edward III (1985), implementasi kebijakan dapat dicapai dengan baik apabila terpenuhi beberapa faktor yang mempengaruhinya. Faktor-faktor yang mempengaruhi tersebut diantaranya adalah komunikasi, sumber daya, disposisi, dan struktur birokrasi. Pertama, yaitu faktor komunikasi, dimana terjadi proses atau aktivitas penyampaian informasi yang berisikan pesan tertentu kepada pemangku kebijakan agar mereka mengetahui dan memahami apa saja yang perlu dipersiapkan dalam melaksanakan suatu kebijakan. Apabila hal tersebut dapat berjalan dengan baik, maka tujuan besar dari kebijakan yang diharapkan dapat tercapai. Kedua, yaitu sumber daya, dimana faktor ini meliputi beberapa aspek seperti ketersediaan sumber daya manusia, keuangan, fasilitas, peralatan, perlengkapan, kewenangan dan informasi. Ketiga, yaitu disposisi, dimana faktor ini menjelaskan tentang suatu kehendak dan keinginan para pemangku kebijakan untuk menjalankan kebijakan secara penuh tanggung jawab sehingga tujuan kebijakan untuk baik dan ideal itu dapat terwujud. Keempat, yaitu struktur birokrasi, dimana dalam untuk menunjang berhasilnya suatu pelaksanaan kebijakan maka perlu ada sebuah mekanisme kerja yang jelas dalam rangka pengelolaan dan pengaturan kegiatan terutama yang melibatkan sejumlah lembaga atau institusi terkait. Hal ini bisa diwujudkan dengan dibuatkannya sebuah Standard Operating Procedure (SOP).

Pemerintah Kota Bandung sebenarnya telah mengeluarkan Peraturan Walikota Nomor 1005 tahun 2014 tentang Harga Sewa Parkir sebagai suatu kebijakan. Kebijakan tersebut kemudian didukung oleh adanya petunjuk teknis pengelolaan perparkiran yang mengatur secara lebih spesifik untuk di gedung dan pelataran parkir Kota Bandung. Secara ideal, peraturan ini diharapkan mampu meningkatkan pendapatan asli daerah dari sektor pajak parkir dan memperbaiki pengelolaan penyelenggaraan tempat parkir di Kota Bandung semakin tertata baik dan rapih. Ketersediaan lahan parkir di Kota Bandung belum tertata dengan baik dan fasilitas untuk perparkiran juga belum memadai, dan hanya sebagian kecil gedung penyedia lahan parkir yang memiliki sistem parkir yang baik. Melihat kondisi Kota Bandung sebagai salah satu kota madya tentu ini menjadi salah satu pekerjaan rumah. Selain itu sumber daya manusia pengelola perparkiran di Kota Bandung juga belum teratur dengan baik oleh pemerintah sebagai salah satu dampaknya ialah munculnya para juru parkir ilegal di setiap ruas jalan sepanjang pasar, tempat-tempat wisata, supermarket dan di berbagai titik keramaian di Kota Bandung. Para jukir ilegal ini memungut pajak parkir $100 \%$ untuk keuntungan sendiri.

Apabila melihat pada pelaksaan dari kebijakan tersebut, dapat dianggap masih belum berjalan dengan baik berdasarkan data dan dari hasil observasi yang dilakukan oleh peneliti. Peneliti menemukan di lapangan bahwa masih ada beberapa ketidaksesuaian peraturan yang telah ditetapkan pemerintah terutama dalam Perwal No 1005 Tahun 2004 dengan realisasi di lapangan diantaranya yaitu dalam Bab IV pasal 4 harga sewa parkir kendaraan yang ditetapkan di tarif lebih tinggi dari peraturan yaitu untuk kendaraan roda dua paling tinggi Rp. 1.500-, per jam namun realita lapangan yang ditemukan oleh peneliti terutama di penyelenggaraan parkir Gasibu Kota Bandung, dalam karcis yang tertera ialah tarif Rp. 3000, untuk kendaraan roda dua. 
Tingginya angka pelanggaran parkir liar di Kota Bandung terutama yang terjadi di sepanjang Jalan Kosambi, Ujung Berung dan beberapa jalan utama di Kota Bandung banyak dijumpai parkir liar di trotoar yang seharusnya dipergunakan oleh para pejalan kaki. Sepanjang tahun 2016 tercatat pelanggaran parkir liar oleh kendaraan roda empat sebanyak 2.435 dan pelanggaran oleh kendaraan roda dua sebanyak 1.487 yang ditertibkan dalam patroli oleh tim Dinas Perhubungan Kota Bandung (sumber: Seksi Penertiban Dinas Perhubungan Kota Bandung) menunjukkan pengelolaan perparkiran di kota Bandung belum berjalan dengan maksimal.

Meningkatnya penyedia sarana tempat parkir di Kota Bandung yang tidak membayar pajak atau tidak tercatat sebagai wajib pajak. Berdasarkan data yang peneliti temukan yaitu pada tahun 2017 data wajib pajak aktif sebanyak 1581 dan non aktif sebanyak 688tempat parkir (sumber: Badan Pengelolaan Pendapatan Daerah kota Bandung). Seharusnya angka wajib pajak parkir di Kota Bandung lebih dari angka tersebut karena banyaknya penyelenggara penyedian jasa parkir yang di temukan di sepanjang pelantaran jalan atau gedung di kota Bandung. Dalam Perwal No 1005 tahun 2014 dalam Bab VI Pasal 6 disebutkan bahwa penyelenggara perparkiran wajib memiliki IPTP (Izin Pengelolaan Tempat Parkir) yang berarti mengantongi izin dan tercatat sebagai wajib pajak parkir dan harus menyetorkan pajak parkir sebesar $25 \%$ dari pendapatan dari parkir setiap bulannya kepada pemerintahmelalui dinas yang telah ditunjuk.

Penyusunan target penerimaan pajak parkir dari tahun ke tahun selalu meningkat dikarenakan meningkatnya pula jumlah para wajib pajak yang ada di Kota Bandung. Apabila kita mengacu data diatas mengenai realisasi penerimaan pajak parkir di Kota Bandung, Penerimaan Pajak Parkir beberapa tahun kebelakang yaitu dari tahun 2013 s/d 2016 mengalami naik turun dan peningkatan yang kurang signifikan, kemudian pada tahun 2015 penerimaan Pajak Parkir mengalami penurunan yang sangat signifikan dari target. Maka berdasarkan latar belakang di atas, maka penulis tertarik untuk melakukan penelitian dengan tujuan yaitu untuk menganalisis implementasi kebijakan pengelolaan perparkiran di gedung dan pelataran parkir Kota Bandung.

\section{Metode Penelitian}

Dalam metode penelitian ini, kualitatif dipilih sebagai sebuah pendekatan, dengan jenis penelitian deskriptif. Penelitian ini ingin memberikan gambaran mengenai implementasi kebijakan pengelolaan perparkiran di Kota Bandung. Dalam rangka untuk mendapatkan data penelitian, maka peneliti menggunakan wawancara mendalam secara terstuktur. Dalam melakukan wawancara tersebut, peneliti kemudian perlu menentukan sejumlah informan, yang dalam hal ini memakai teknik sampel purposive. Ini artinya bahwa peneliti memilih sejumlah informan yang secara sengaja dipilih oleh peneliti dengan tujuan tertentu, karena dianggap memiliki karakteristik yang berkaitan langsung dengan proses penelitian ini sehingga dapat memperkaya data penelitian. Selain itu penelitian ini menggunakan studi kepustakaan, yaitu data penelitian yang diperoleh dari studi literatur serta tulisan lain yang berhubungan dengan penelitian. Mengumpulkan data dengan cara mempelajari buku-buku dan dokumen yang berhuubungan dengan pokok-pokok penelitian. Dalam menganalisis data, penelitian ini menggunakan analisis data kualitatif, dimana peneliti memilah dan memilih serta menyusun data hasil dari wawancara, catatan lapangan, dan bahan-bahan lainnya secara sistematis, teratur, dan koheren. Sehingga dapat mudah dipahami, dilakukan dengan mengorganisasikan data, menjabarkannya kedalam unit-unit, melakukan sintesa, menyusun kedalam pola mana yang penting dan yang akan dipelajari dan membuat kesimpulan yang dapat dicirikan kepada orang lain. 


\section{Hasil Dan Pembahasan}

Pada saat ini, pemerintah sedang gencar-gencarnya menjadi pusat perhatian publik yang tentunya berkaitan dengan kebijakan publik. Sementara itu, hal yang mengemuka ke ranah publik diantaranya kritik bahwa pemerintah terlihat tidak bekerja sehingga menimbulkan opini publik bahwa fungsi pemerintah dalam hal ini terlihat sangat lemah karena proses dalam melaksanakan implementasi kebijakan tersebut tidak berjalan dengan baik. Fenomena yang terjadi yaitu pegawai negeri ada yang terlihat bekerja secara serampangan, tidak memberikan pelayanan yang baik, serta dalam melaksanakan pekerjaan masih kurang efektif dan efisien. Maka, tanpa adanya implementasi yang efektif apapun keputusan yang dibuat oleh pembuat kebijakan tidak akan menuai keberhasilan dalam pencapaiannya.

Apabila dilihat dari hasil penelitian yang penulis lakukan di lapangan mengenai Implementasi Peraturan Walikota Bandung No 1005 Tahun 2014 Tentang Harga Sewa Parkir dan Petunjuk Teknis Pengelolaan Perparkiran di Gedung dan Pelataran Parkir di Kota Bandung tersebut, jika dikaitkan dengan teori yang dimiliki oleh Edward III yang di dalam teori itu terdapat empat dimensi yaitu Komunikasi, Sumber Daya, Disposisi, dan Struktur Birokrasi sebagaimana keempat dimensi itu merupakan variabel yang tentunya sangat berperan penting dalam menunjang keberhasilan suatu implementasi.

Maka dari itu, dalam proses pelaksanaan yang dilakukan oleh Badan Pengelolaan Pendapatan Daerah Kota Bandung terkait Implementasi Peraturan Walikota Bandung Nomor 1005 Tahun 2014 Tentang Harga Sewa Parkir dan Petunjuk Teknis Pengelolaan Perparkiran di Gedung dan Pelataran Parkir di Kota Bandung apabila direlevansikan dengan teori dari Edward III tersebut adalah sebagai berikut.

\section{Komunikasi}

Komunikasi merupakan suatu proses dalam penerimaan dan penyampiaan berita sebagaimana informasi yang dilakukan oleh seseorang ke orang lain. Salah satu kunci agar implementasi dalam suatu kebijakan itu dapat berjalan secara efektif, para pelaksana kebijakan sebagai implementor yang bertanggungjawab atas berjalannya suatu keputusan perlu mengetahui apa yang dilakukan para pelaksana yang ada di lapangan. Perintah untuk melaksanakan kebijakan itu harus dapat disebarkan pada para pegawai lainnya yang tepat dan aturan tersebut harus akurat, konsisten serta jelas. Faktor-faktor yang dapat mempengaruhi tingkat konsistensi antara lain menyangkut kerumitan kebijakan publik, masalah-masalah yang mengawali program-program baru dan banyaknya ketidak jelasan tujuan. Ketidakkonsisten, seperti halnya kekaburan berasal dari semakin besarnya kepentingan yang bersaing yang berusaha untuk memengaruhi implementasi kebijakan. Keadaan seperti itu akan mendorong kemungkinan perintah-perintah implementasi tidak konsisten.

Untuk dimensi komunikasi ini,pertama peneliti menanyakan apakah Perwal No 1005 Tahun 2014 tentang Harga Sewa Parkir dan Petunjuk Teknis Pengelolaan Perparkiran di Gedung dan Pelataran Parkir di Kota Bandung sudah jelas dan dapat dimengerti, berikut pernyataan dari Kepala Badan Pengelolaan Pendapatan Daerah Kota Bandung:

"Sudah sangat jelas dan wajib dipahami oleh seluruh pegawai yang menjalankan tugasnya terkait dengan Perwal ini. Bagi pegawai yang belum mengerti akan diadakan pembinaan terkait implementasi dari perwal ini agar pelaksaan berjalan efektif dan efisien, jadi sangat penting untuk 
memahami perwal ini." (kamis, 4 April 2019 Pukul 09.00 di BPPD Kota Bandung).

Sejalan dengan pendapat tersebut Kepala Bidang Perencanaan dan Penyuluhan juga mengemukakan sebagai berikut:

"Kalau menurut saya pribadi Perwal ini sudah jelas dan cukup mudah dimengerti terutama oleh pegawai yang langsung berkerja dalam pelaksaaan Perwal ini"(Kamis, 4 April 2019 Pukul 09.00 di BPPD Kota Bandung).

Kedua peneliti menanyakan Apakah pegawai sudah memahami maksud yang dikomunikasikan terkait implementasi perwal no 1005 tahun 2014 tentang Harga Sewa Parkir dan Petunjuk Teknis Pengelolaan Perparkiran di Gedung dan Pelataran Parkir di Kota Bandung. Berikutpernyataan yang dikemukakan oleh Kepala Badan Pengelolaan Pendapatan Daerah Kota Bandung:

"Kalau pegawai mah harus, apalagi pengelola parkir tidak boleh tidak mengerti. Harus mengerti harus jelas dan bisa dibaca. Jika ada yang tidak dimengerti pegawai wajib menanyakan kepada atasan tentang maksud dan tujuan dari sebuah peraturan dalam hal ini yaitu peraturan walikota no 1005 tahun 2014" (Kamis, 4 April 2019 Pukul 09.00 di BPPD Kota Bandung).

Demikian pula menurut Kepala Sub Bidang Data dan SistemInformasi adalah sebagai berikut:

"Ya, sudah dapat dipahami dilihat dari lancarnya komunikasi yang terjadi dalam pelaksaan tugas” (Kamis, 4 April 2019 Pukul 09.00 di BPPD Kota Bandung).

Dari hasil wawancara tersebut maka untuk dimensi komunikasi dalam implementasi kebijakan Perwal No 1005 Tahun 2014 tentang Harga Sewa Parkir dan Petunjuk Teknis Pengelolaan Perparkiran di Gedung dan Pelataran Parkir di Kota Bandung sudah terlaksana dengan baik dimana peraturan tersebut sudah dapat dan wajib dipahami oleh semua pegawai di BPPD kota Bandung.

Adapun berdasarkan hasil pengamatan peneliti dilapangan bahwa komunikasi dalam implementasi perwal tersebut sudah jelas dan tidak ada masalah, baik dalam pemahaman maksud dan tujuan dari perwal tersebut juga komunikasi dari atasan dan bawahan berjalan dengan baik karena setiap elemen melakukan setiap pekerjaan itu sesuai prosedur yang ada. Menurut Edward III (1985) bahwa suatu implementasi yang baik itu adanya kejelasan, jika kebijakan-kebijakan diimplementasikan sebagaimana yang diinginkan, maka petunjukpetunjuk pelaksana tidak hanya harus diterima oleh para pelaksana kebijakan, tetapi juga komunikasi kebijakan tersebut harus jelas.

\section{Sumber Daya}

Sumber daya merupakan aspek yang tidak kalah pentingnya dalam proses implementasi suatu kebijakan karena suatu kebijakan harus didukung oleh sumber daya yang 
memadai, baik Sumber Daya Manusia (SDM) seperti staf yang merupakan sumber daya yang paling penting yang harus dimiliki oleh setiap organisasi terkait kecukupan jumlah pegawai yang tersedia dan pegawai yang berkompeten akan menunjang laju dari organisasi tersebut. Selain Sumber Daya Manusia (SDM), sumber daya Peralatan seperti penggunaan teknologi informasi yang sudah memadai dan mendukung dalam pelayanan pajak parkir. Kedua aspek tersebut harus diperhatikan dalam implementasi kebijakan dan sasaran program pemerintah yang ingin dicapai sebab tanpa kompetensi yang dimiliki oleh para implementor, kebijakan cenderung tidak efektif sehingga akan berjalan dengan begitu lambat dan seadanya.

Sesuai dengan wawancara yang dilakukan oleh penulis dilapangan terkait Sumber Daya Manusia (SDM) yang ada di BPPD Kota Bandung informan yang menduduki jabatan sebagaiKepala Badan Pengelolaan Pendapatan Daerah Kota Bandung. Peneliti memberikan beberapa pertanyaan yaitu pertama, apakah SDM di BPPD sudah kompeten dalam implementasi Perwal No 1005 tahun 2014 tentang Harga Sewa Parkir dan Petunjuk Teknis Pengelolaan Perparkiran di Gedung dan Pelataran Parkir di Kota Bandung. Berikut penyataannya:
"Menurut saya sudah, karena sebagian besar pegawai merupakan pegawai yang telah berkecimpung cukup lama dalam menjalani pemungutan pajak parkir di kota Bandung. Adapun pegawai baru akan mendapatkan pelatihan terlebih dahulu sebelum terjun ke lapangan." (Kamis, 4 April 2019 Pukul 09.00 di BPPD Kota Bandung).

Sebagaimana pernyataan tersebut, Kepala Bidang Perencanaan dan Penyuluhan BPPD Kota Bandung juga menyatakan sebagai berikut:

"Menurut kami sudah, karena pegawai sebelum terjun ke lapangan diberikan pelatihan kelayakan agar mereka bisa menjalankan tugas dengan baik dan memiliki kompetensi sesuai standar pelaksanaan tugas dan fungsi." (Kamis, 4 April 2019 Pukul 09.00 di BPPD Kota Bandung).

Kedua, peneliti menanyakan bagaimana pegawai dalam menjalankanTupoksinya. Berikut pernyataan yang ungkapkan oleh Kepala Badan Pengelolaan Pendapatan Daerah Kota Bandung:
"Ya mereka harus menjalankan sesuai tupoksi, outputnya yaitu tercapainya target dan tidak boleh banyak komplain. Setiap pegawai wajib menjalankan tugasnya sesuai dengan tupoksi, tidak boleh melenceng sedikitpun dari tupoksi tersebut. Bagi pegawai yang kedapatan melenceng tidak sesuai prosedur maka akan mendapatkan tindak lanjut langkah pertama yaitu dengan memberikan surat tanda peringatan karena tupoksi ini bersifat wajib untuk diikuti bagi setiap pegawai" (Kamis, 4 April 2019 Pukul 09.00 di BPPD Kota Bandung).

Adapun berikut ini adalah pernyataan dari Sub Bidang Survey dan Data Wajib Pajak:
"Ya, setiap pegawai memang harus diwajibkan bekerja berdasarkan tupoksi yang telah ditetapkan sebelumnya agar efektivitas dan efisiensi kerja bisa berjalan secara optimal." (Kamis, 4 April 2019 Pukul 09.00 di BPPD Kota Bandung).

Ketiga, peneliti menanyakan Bagaimana kewenangan staf yang bertugas dalam implementasi Perwal No 1005 tahun 2014 tentang Harga Sewa Parkir dan Petunjuk Teknis 
Pengelolaan Perparkiran di Gedung dan Pelataran Parkir di Kota Bandung. Berikut ini yang dikemukakan oleh Kepala Badan Pengelolaan Pendapatan Daerah Kota Bandung:

"Oh tidak boleh mengambil kebijakan sendiri, yang namanya staf itu hanya melaksanakan tugas sesuai tupoksi. Tidak memiliki kewenangan dalam mengambil keputusan harus mengikuti perintah dari atasan." (Kamis, 4 April 2019 Pukul 09.00 di BPPD Kota Bandung).

Sejalan dengan pendapat tersebut, Kepala Sub Bidang Pajak Hiburan dan Parkir juga mengemukakan sebagai berikut:

"Staf hanya menjalankan tugas berdasarkan perintah dan tupoksi, tidak memiliki kewenangan yang spesial, di mana staf harus patuh dan taat pada atasan” (Kamis, 4 April 2019 Pukul 09.00 di BPPD Kota Bandung).

Keempat, peneliti menanyakan Bagaimana pemanfaatan teknologi informasi yang dimiliki dalam implementasi Perwal No 1005 Tahun 2014. Adapun berikut ini pernyataan dari Kepala BPPD Kota Bandung perihal pertanyaan tersebut:

"Teknologi informasi dalam artian mensukseskan program parkir di antaranya adalah dengan pemasangan Taping Blok untuk parkir-parkir besar. Taping blok itu adalah alat yang dipasang untuk menyadap transaksi parkir yang dilaksanakan di suatu tempat itu berapa jumlah parkir yang masuk dalam satu hari bisa tersadap oleh sistem kita. Adapun masalah pelaporan pajaknya dalam bidang teknologi mereka tidak perlu datang ke BPPD cukup dengan membayar dengan menggunakan aplikasi E-Satria, di sana ada sistem pelaporan pajak parkir dan pembayaran itu langsung dilakukan di Bank Jabar." (Kamis, 4 April 2019 Pukul 09.00 di BPPD Kota Bandung).

Sementara itu, berikut yang diungkapkan oleh Kepala Bidang Perencanaan dan Penyuluhan:

"Sudah cukup baik, dibuktikan dengan segala input dan output dalam pemungutan pajak parkir sudah menggunakan sistem komputerisasi dan para pegawai kami dituntut untuk mahir dalam menjalankan berbagai aplikasi layanan pemungutan pajak parkir." (Kamis, 4 April 2019 Pukul 09.00 di BPPD Kota Bandung).

Kelima, peneliti menanyakan bagaimana pegawai dalam mempertanggung jawabkan hasil pekerjaannya dalam implementasi Perwal No 1005 tahun 2014 tentang Harga Sewa Parkir dan Petunjuk Teknis Pengelolaan Perparkiran di Gedung dan Pelataran Parkir di Kota Bandung. Berikut ini yang diungkapkan oleh Kepala BPPD Kota Bandung:

"Dalam memepertanggungjawabkan hasil pekerjaannya yaitu melalui laporan secara berkala dari setiap bidang yang melaksanakan pemungutan pajak parkir baik itu petugas di kantor maupun petugas di lapangan, setiap sub bidang memiliki laporan dan wajib disetorkan kepada atasan." (Kamis, 4 April 2019 Pukul 09.00 di BPPD Kota Bandung).

Selanjutya di bawah ini pendapat dari Kepala Sub Bidang Data dan Sistem Informasi: 
"Di sisni pertanggungjawaban hasil pekerjaan itu berbentuk laporan secara berkala yang nantinya puncak dari hasil pertanggungjawaban akan dilakukan fdalam LPJ akhir tahun secara keseluruhan. Yang namanya pegawai ya wajib bertanggungjawab kepada atasan." (Kamis, 4 April 2019 Pukul 09.00 di BPPD Kota Bandung).

Kelima, peneliti menanyakan Bagaimana petugas dalam mengelola potensi parkir. Berikut ini yang diungkapkan oleh Kepala BPPD Kota Bandung:

"Petugas wajib melihat potensi parkir yang ada di kota bandung jika menemukan penyewaan tempat parkir yang belum mendaftarkan usahanya dalam pajak parkir akan diberikan surat peringatan agar segera mendaftarkan menjadi wajib pajak parkir jika tidak maka akan dipaksa secara hukum dan peraturan yang berlaku di Kota Bandung." (Kamis, 4 April 2019 Pukul 09.00 di BPPD Kota Bandung).

Sejalan dengan pendapat tersebut, Kepala Sub Bidang Survey dan Data Wajib Pajak juga mengatakan hal serupa sebagai berikut:

"Petugas dalam artian mengelola ya mereka harus senantiasa potensi parkir tersebut diawasi bagaimana mereka melihat potensi parkir yang baru maupun yang lama dan juga harus mengawasi perkembangan dari potensi parkir yang ada." (Kamis, 4 April 2019 Pukul 09.00 di BPPD Kota Bandung).

Dari hasil wawancara tersebut maka dapat dikatakan SDM BPPD Kota Bandung dalam melaksanakan Perwal Nomor 1005 Tahun 2014 sudah kompeten, yang mana pegawainya telah diberikan posisi sesuai dengan pengalaman dan keahlian yang dimilikinya yang tentunya hal ini akan memudahkan pegawai tersebut dalam menjalankan tupoksinya dalam pencapaian tujuan dan sasaran yang telah ditetapkan. Kemudian adanya penggunaan teknologi informasi dan komunikasi dalam pelayanan pajak parkir sudah cukup baik dengan adanya peralatan seperti komputer dan aplikasi e-satria sehingga memudahkan dalam pemungutan pajak parkir, pegawai menjalankan tugasnya sesuai tupoksinya masing-masing dan mempertanggungjawabkan tugas yang telah dilaksanakannya dalam bentuk laporan.

\section{Disposisi}

Disposisi mengandung maksud sebagai sikap para penyelenggara kebijakan. Disposisi merupakan hal yang krusial dimana para pejabat birokrasi sebagai implementor perlu mengetahui pengaruh-pengaruh tertentu pada sikap atau tingkah laku mereka dalam melaksanakan kebijakan tersebut. Oleh karena itu, dalam melaksanakan setiap kebijakan mereka harus memiliki karakter yang jujur, dapat berkomitmen dan demokratis karena ketiga karakter utama itulah yang harus dimiliki oleh para implementor.

Implementor yang dalam dirinya memiliki karakter jujur dan berkomitmen tinggi akan senantiasa dapat memajukan organisasi yang dia naungi dan implementor yang seperti itu dapat bertahan diantara hambatan yang ada dalam proses pelaksanaan kebijakan dan program yang sedang dijalankan. Oleh sebab itu, kejujurannya dan komitmennya dapat mengarahkan seorang implementor tersebut untuk tetap teguh berada dalam arah program yang telah ditentukan sesuai dengan kebijakan yang ada sedangkan sikap demokratis itu sebagai pelengkap, dimana dengan seorang implementor tersebut memiliki sikap demokratis itu akan meningkatkan kesan baik terhadap dirinya dihadapan anggotanya. 
Terkait sikap pelaksana para pegawai yang terdapat di BPPD Kota Bandung, peneliti menanyakan Apakah perintah dari pimpiman berkaitan dengan implementasi Perwal No 1005 Tahun 2014 tentang Harga Sewa Parkir dan Petunjuk Teknis Pengelolaan Perparkiran di Gedung dan Pelataran Parkir di Kota Bandung dilaksanakan dengan baik. Adapun berikut ini jawaban dari Kepala BPPD Kota Bandung:

"Sudah dilaksanakan dengan cukup baik karena pimpinan memberikan instruksi dengan jelas dan dapat dipahami oleh semua pegawai." (Kamis, 4 April 2019 Pukul 09.00 di BPPD Kota Bandung). Penyuluhan:

Sementara itu, berikut ini yang diungkapkan oleh Bidang Perencanaan dan

"Wajib dilaksanakan pegawai dengan sebaik-baiknya karena putusan pimpinan wajib diikuti di samping mengikuti tupoksi yang ada apabila pegawai tidak melaksanakan pekerjaan dengan baik maka pegawai tersebut bisa di resign."(Kamis, 4 April 2019 Pukul 09.00 di BPPD Kota Bandung).

Kedua, peneliti menanyakan Apakah perintah yang tertulis dalam disposisi terkait perwal no 1005 tahun 2014 tentang Harga Sewa Parkir dan Petunjuk Teknis Pengelolaan Perparkiran di Gedung dan Pelataran Parkir di Kota Bandung dapat dimengerti dan dipahami. Berikut pernyataan Kepala BPPD Kota Bandung:

"Pegawai sebelum melaksanakan tugasnya dan terjun ke lapangan harus membaca setiap perintah yang tertulis dan prosedur yang tidak tertulis itu semua dilatih dalam masa magang pegawai."(Kamis, 4 April 2019 Pukul 09.00 di BPPD Kota Bandung).

Sejalan dengan pendapat tersebut, Kepala Sub Bidang Data dan Sistem Informasi juga mengatakan sebagai berikut:

"Ya, wajib hukumnya setiap pegawai mematuhi perintah dan memahami perintah baik yang tertulis dalam disposisi maupun periintahh dalam bentuk lisan dari pimpinan atau dari atasan." (Kamis, 4 April 2019 Pukul 09.00 di BPPD Kota Bandung).

Ketiga, peneliti menanyakan bagaimana cara menyelesaikan potensi parkir yang belum terdaftar, berikut ini pernyataan dari Kepala BPPD Kota Bandung:

"Cara yang utama yaitu dengan menghimbau melalui iklan-iklan atau spanduk-spanduk agar mereka paham kewajiban membayar parkir jika belum mendaftarkan diri maka akan dikeluarkan surat peringatan dari atasan dan dilayangkan kepada wajib pajak yang belum mendaftarkan dirinya." (Kamis, 4 April 2019 Pukul 09.00 di BPPD Kota Bandung).

Selanjutnya berikut ini pernyataan dari Sub Bidang Data dan Sistem Informasi terkait penyelesaian potensi parkir yang belum terdaftar:

"Nah ini merupakan salah satu masalah yang terjadi dalam implementasi perwal ini karena masih banyaknya wajib pajak yang belum mendaftarkan diri. Seejauh ini kami sudah melakukan penghimbauan kepada wajib pajak dan memberikan surat peringatan agar segera mendaftarkan diri namun 
pada kenyataannya masih banyak dari mereka yanng mengabaikan surat tersebut.” (Kamis, 4 April 2019 Pukul 09.00 di BPPD Kota Bandung).

Keempat, peneliti menanyakan Strategi apa yang diterapkan untuk mengelola potensi parker, berikut pernyataan dari Kepala BPPD Kota Bandung:

"Strateginya tetap mengawasi tetap mengendalikan yang tadi yang belum mendaftarkan diri akan kita paksa atau kita paksa untuk mendaftar kita keluarkan NPWP kemudian kita hitung potensinya dan kita awasi dan kendalikan pendapatan mereka sehingga tidak sesuka hatinya tapi sesuai dengan potensi." (Kamis, 4 April 2019 Pukul 09.00 di BPPD Kota Bandung).

Sementara itu, berikut ini adalah yang dikemukakan oleh kepala Sub Bidang Data dan Sistem Informasi:

"Menurut kami masih menggunakan strategi lama yaitu pengendalian agar para wajib pajak sadar dan siuman sehingga sadar untuk membayar pajak."(Kamis, 4 April 2019 Pukul 09.00 di BPPD Kota Bandung).

Berdasarkan hasil penelitian dilapangan yang dilakukan oleh peneliti disposisi dari perwal ini belum berjalan dengan baik terutama dalam strategi yang dilakukan oleh pegawai BPPD sendiri dalam menyerukan pembayaran pajak parkir kepada masyarakat juga tidak adanya pembaharuan ide yang dapat membuat lebih banyak lagi wajib pajak parkir, berdasarkan hasil wawancara diatas para petugas masih mengandalkan himbauan tertulis dan iklan-iklan yang kurang massiv dan menarik. Harusnya ada ide terbaru seperti melakukan sebuah kebijakan yang menarik para wajib pajak yang belum mendaftarkan dirinya.

Dari hasil wawancara dan hasil penelitian lapangan tersebut maka dapat disimpulkan bahwa disposisi dalam implementasi kebijakan Perwal Nomor 1005 tahun 2014itu belum berjalan dengan baik, karena tidak adanya pembaharuan strategi yang dilakukan oleh pegawai BPPD Kota Bandung.

\section{Struktur Birokrasi}

Struktur birokrasi menjadi suatu hal yang penting dalam mendukung suksesnya implementasi kebijakan. Struktur birokrasi ini merupakan suatu susunan yang berada di dalam organisasi pemerintahan sehingga mereka melaksanakan kebijakan dan tentunya memiliki pengaruh penting pada implementasi tersebut. Terdapat dua karakteristik yang utama dalam birokrasi yaitu Standar Operasional Prosedur (SOP), sebagai tanggapan pihak internal terhadap waktu yang terbatas dan keinginan para pelaksana untuk keseragaman dalam bekerja. Standar Operasional Prosedur (SOP) yang baik itu dapat mencantumkan suatu kerangka kerja yang sukup jelas, mudah dipahami sehingga tidak berbelit-belit dan sistematis maka dengan terpenuhinya seluruh aspek tersebut dalam Standar Operasional Prosedur (SOP), akan menjadi acuan dalam bekerjanya para pelaksana kebijakan. Karakteristik selanjutnya yaitu fragmentasi yang berasal dari tekanan-tekanan di luar unit birokrasi seperti, komite legislatif dan kelompok kepentingan.

Untuk dimensi struktur birokrasi ini, pertama peneliti menanyakan Apakah stuktur yang ada sudah mencukupi. Berikut pernyataan dari Kepala BPPD Kota Bandung: 
"Menurut saya belum ya, karena ada 1500 wajib pajak yang terdaftar dan hanya dikelola oleh 7 orang pegawai pajak parkir. "(Kamis, 4 April 2019 Pukul 09.00 di BPPD Kota Bandung).

Selanjutnya berikut ini pernyataan dari Bidang Perencanaan dan Penyuluhan BPPD Kota Bandung:

"Kurang perlu penambahan pegawai lagi atau upgrade sistem ke yang lebih baik sehingga tidak terjadi penumpukan pekerjaan oleh pegawai." (Kamis, 4 April 2019 Pukul 09.00 di BPPD Kota Bandung).

Kedua, peneliti menanyakan Bagaimana pemimpin dalam melaksanakan kepemimpinannya. Berikut yang dikemukakan oleh Kepala BPPD Kota Bandung:

"Pemimpin menjalankan sesuai peraturan,, peran dan tugasnya. Sudah cukup baik dalam mengawasi pegawai atau stafnya." (Kamis, 4 April 2019 Pukul 09.00 di BPPD Kota Bandung).

Selanjutnya berikut ini yang dikemukakan oleh oleh Kepala Sub Bidang Survey dan Data Wajib Pajak:

"Saya pribadi menyukai gaya kepemimpinan pemimpin saat ini di mana beliau tidak bersikap seperti atasan tapi menjadi partner untuk setiap pegawainya dan tegas dalam mengambil keputusan.” (Kamis, 4 April 2019 Pukul 09.00 di BPPD Kota Bandung).

Ketiga, peneliti menanyakan Bagaimana pemimpin dalam mengambil keputusan terkait perwal no 1005 tahun 2014 di Kota Bandung. Berikur pernyataan dari Kepala BPPD Kota Bandung:

"Saya pribadi mengambil keputusan itu sesuai dengan peraturan jika belum tercantum dalam peraturan maka saya akan bermusyawarah terlebih dahulu." (Kamis, 4 April 2019 Pukul 09.00 di BPPD Kota Bandung). Informasi:

Sementara itu, berikut ini yang dikemukakan oleh Sub Bidang Data dan Sistem

"Kadang ketika permasalahan lapangan yang tidak terdapat dalam aturan, pemimpin melakukan musyawarah untuk mengambil keputusan dan saya sangat menyukai itu. "(kamis, 4 April 2019 Pukul 09.00 di BPPD Kota Bandung).

Keempat, peneliti menanyakan Apakah dalam melaksanakan tugas sudah sesuai dengan tupoksi. Berikut ini adalah pernyataan dari Kepala BPPD Kota Bandung:

"Harus sesuai tupoksi karena semuanya ada SOP nya, jika keluar dari SOP maka akan terjadi masalah atau hambatan. Jangankan oleh aparat hukum oleh masyarakat pun akan mendapatkan komplain." (Kamis, 4 April 2019 Pukul 09.00 di BPPD Kota Bandung). 
Sejalan dengan pendapat tersebut, Kepala Sub Bidang Survey dan Data Wajib Pajak juga mengatakan sebagai berikut:

"Wajib dong, karena jika tidak sesuai SOP pegawai akan mendapatkan teguran ari pengawas begitu juga dengan pemimpin akan mendapat teguran dari pengawas. ” (Kamis, 4 April 2019 Pukul 09.00 di BPPD Kota Bandung).

Kelima, peneliti menanyakan Bagaimana tanggapan bawahan terhadap putusan atasan. Berikut sebagaimana jawaban dari Kepala BPPD Kota bandung:

"Kalau tanggapan mau tidak mau harus mengikuti atasan, namun atasan dalam mengabil setiap putusan harus berdasarkan fakta dan bukti yang sesuai dengan aturan yang berlaku dan tidak semenqa-mena. Pasti harus nurut karena itu adalah konsekuensi sebagai bawahan terhadap atasan.' (Kamis, 4 April 2019 Pukul 09.00 di BPPD Kota Bandung).

Sementara itu, berikut ini yang diungkapkan oleh kepala Bidang Perencanaan dan Penyuluhan:

"Setiap bawahan harus mengikuti putusan atasan selagi putusan tersebut diambil sesuai peraturan dan tidak ada yang melanggar namun jika putusan tersebut melanggar maka akan dikenakan sanksi." (Kamis, 4 April 2019 Pukul 09.00 di BPPD Kota Bandung).

Dari hasil wawancara tersebut, maka untuk dimensi struktur birokrasi peneliti dapat menyimpulkan bahwa struktur birokrasi di BPPD Kota Bandung dalam implementasi kebijakan Perwal Nomor 1005 tahun 2014 belum berjalan baik karena masih kurangnya pegawai yang mengelola pemunguatan pajak parkir dan dibutuhkan penambahan pegawai lebih banyak lagi. Namun dalam sikap dan hubungan antara pemimpin dan bawahan sudah berjalan dengan baik.

Selanjutnya dalam proses implementasi Peraturan Walikota Bandung No 1005 Tahun 2014 Tentang Harga Sewa Parkir dan Petunjuk Teknis Pengelolaan Perparkiran di Gedung dan Pelataran Parkir di Kota Bandung ini terdapat beberapa faktor yang menghambat dalam pencapaiannya. Berikut beberapa kendala yang dihadapinya:

1. Sumber Daya

Dari penelitian yang penulis lakukan, penulis mendapatkan bahwa Sumber Daya Manusia (SDM) yang dimiliki oleh Badan Pengelolaan Pendapatan Daerah Kota Bandung untuk petugas jumlahnya masih kurang memadai berdasarkan data dan stuktur birokrasi hanya ada 7 orang pegawai yang mengelola 1.500 wajib parkir yang aktif sementara seharusnya memiliki lebih banyak pegawai agar pencapaian pendapatan dari sektor parkir lebih optimal.

Sumber daya lainnya yaitu terkait sumber daya IT masih kurang memadai karena masyarakat kota Bandung saat ini adalah masyarakat yang melek teknologi sehingga menuntut pemerintah terutama BPPD Kota Bandung untuk memiliki sistem IT yang lebih baik juga dalam sistem penghimbauan pada masyarakat untuk sadar membayar pajak. 
2. Kesadaran publik yang masih kurang terhadap pajak parkir

Khususnya di wilayah Kota Bandung sepanjang jalan protokol dan di pusat keramaian masih kurangnya kesadaran yang dimiliki oleh masyarakat terhadap pajak parkir. Banyak masyarakat yang memiliki penyediaan lahan parkir yang memungut bayaran namun tidak mendaftarkan diri sebagai wajib pajak parkir. Hal inilah yang menyebabkan munculnya para juru parkir ilegal yang memungut bayaran 100\% masuk kantong pribadi padahal jika diolah oleh pemerintah dengan baik akan meningkatkan pendapatan daerah dari sektor parkir.

3. Kurang Aktifnya pemerintah dalam mengkampanyekanmasyarakat untuk sadar membayar pajak parkir

Hal ini dilihat dari tidak adanya pembaharuan strategi yang dilakukan oleh BPPD Kota Bandung untuk menarik masyarakat yang menyediakan lahan parkir yang memungut bayaran sebagaimana informasi yang peneliti dapatkan dari wawancara.

\section{Simpulan}

Dari hasil penelitian yang telah dilakukan oleh peneliti, peneliti dapat menarik kesimpulan bahwa implementasi kebijakan Perwal No 1005 Tahun 2014 tentang Harga Sewa Parkir dan Petunjuk Teknis Pengelolaan Perparkiran di Gedung dan Pelataran Parkir di Kota Bandung belum berjalan optimal. Hal ini dilihat dari beberapa faktor. Pertama untuk komunikasi sudah terlaksana dengan baik dimana peraturan tersebut sudah dapat dan wajib dipahami oleh semua pegawai di BPPD Kota Bandung. Kedua untuk sumber daya sudah kompeten, yang mana pegawainya telah diberikan posisi sesuai dengan pengalaman dan keahlian yang dimilikinya yang tentunya hal ini akan memudahkan pegawai tersebut dalam menjalankan tupoksinya dalam pencapaian tujuan dan sasaran yang telah ditetapkan. Kemudian adanya penggunaan teknologi informasi dan komunikasi dalam pelayanan pajak parkir sudah cukup baik. Ketiga untuk disposisi belum berjalan dengan baik, karena tidak adanya pembaharuan strategi yang dilakukan oleh pegawai BPPD Kota Bandung. Keempat untuk struktur birokrasi belum berjalan baik karena masih kurangnya pegawai yang mengelola pemunguatan pajak parkir dan dibutuhkan penambahan pegawai lebih banyak lagi. Namun dalam sikap dan hubungan antara pemimpin dan bawahan sudah berjalan dengan baik.

\section{Referensi}

Agustino, L. (2008). Dasar-Dasar Kebijakan Publik. Alfabeta, Bandung.

Anggara, S. (2012). Perbandingan Administrasi Negara. Bandung: Pustaka Setia.

Anggara, S. (2015). Metode Penelitian Administrasi. Bandung: Pustaka Setia.

Bungin, B. (2007). Penelitian Kualitatif: Komunikasi, Ekonomi, Kebijakan Publik, dan Ilmu Sosial Lainnya. Jakarta: Kencana.

Islami. (2009). Prinsip-Prinsip Perumusan Kebijaksanaan Negara. Jakarta: Bumi Aksara, Jakarta.

Moenir, H.A.S. (1998). Manajemen Pelayanan Publik, Jakarta: Bina Aksara.

Moleong, L. (2006). Meteologi Penelitian Kualitatif. Bandung: PT. Remaja Rosdakarya. 
Nawawi, I. (2009). PublicPolicy (Analisis, Strategi Advokasi Teori dan Praktek). Surabaya: PMN.

Nugroho, R. (2014). Public Policy. Jakarta: Elek Media Komputindo

Pasolong, H. (2013). Teori Administrasi Publik. Bandung: Alfabeta.

Perwal No 1005 tahun 2014 tentang harga sewa parkir dan petunjuk teknis pengelolaan perparkiran di gedung dan pelataran parkir di kota Bandung.

Siagian, S.P. (2008). Administrasi Pembangunan, Konsep, Dimensi dan Strateginya. Jakarta: Bumi Aksara.

Silalahi, U. (2012). Metode Penelitian Sosial. Bandung: Refika Aditama.

Subarsono, A.G. (2005). Analisis Kebijakan Publik Konsep, Teori dan Aplikasi. Yogyakarta: Pustaka Pelajar.

Sugiyono. (2008). Memahami Penelitian Kualitatif. Bandung: Alfabeta.

Suyanto, B. (2005). Metode Penelitian Sosial Berbagai Alterntif Pendekatan. Jakarta: Prenada.

Suyanto. (2013). Metode Penelitian Sosial Berbagai Alterntif Pendekatan. Jakarta: Prenada.

Thoha, M. (2015). Dimensi-Dimensi Prima Ilmu Administrasi Negara. Raja Grafindo Persada, Jakarta.

Wahab, S.A. (2008). Analisis Kebijaksanaan, dari Formulasi ke Implementasi. Jakarta: Bumi Aksara.

Wahab, S.A. (2008). Pengantar Analisis Kebijakan Publik. Malang: UMM Press.

Winarno, B. (2004). Kebijakan Publik: Teori, Proses, dan Studi Kasus (Edisi dan Revisi Terbaru). Yogyakarta: CAPS.

Widodo, J. (2017). Analisis Kebijakan Publik. Bandung: MNC. 